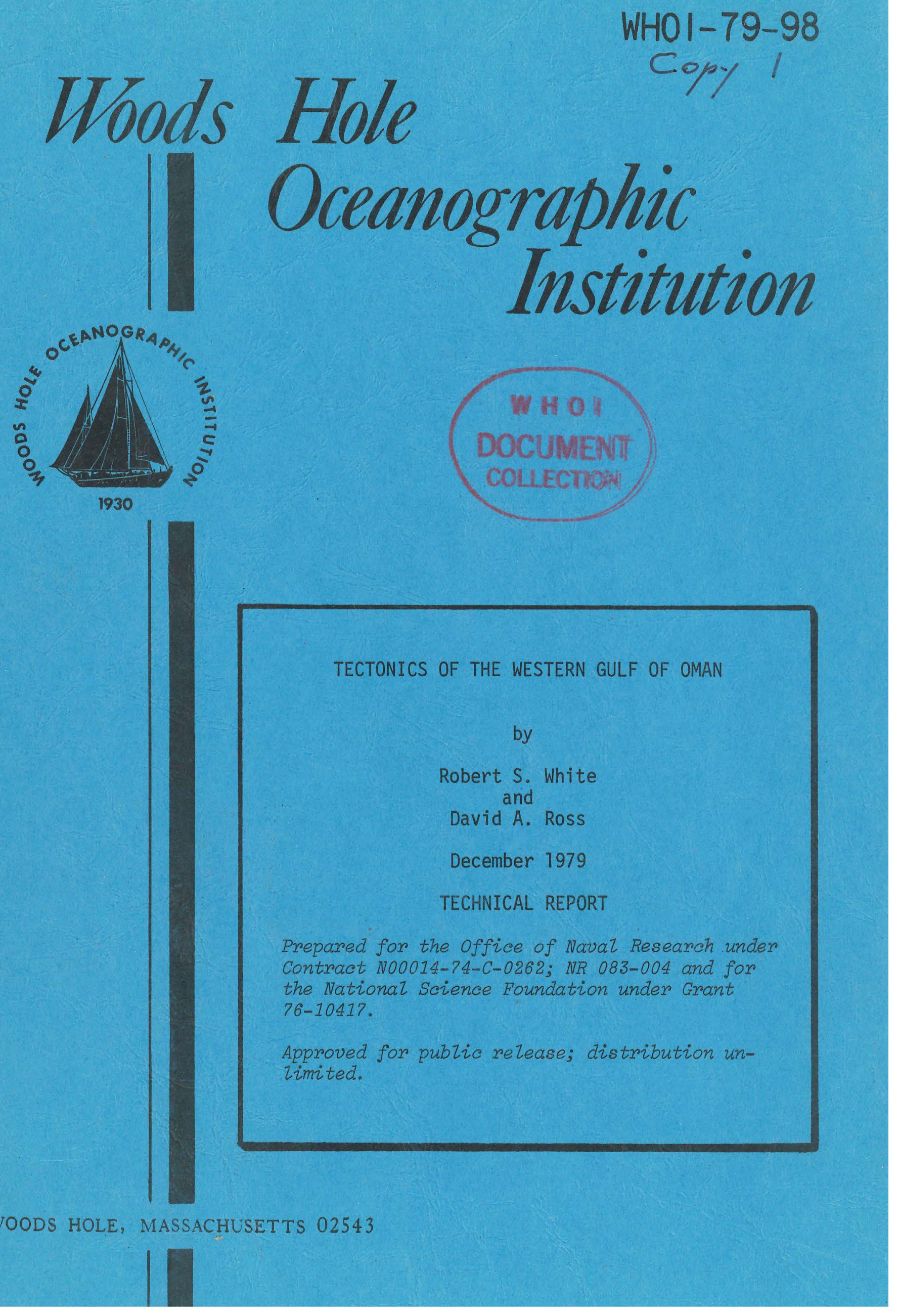


WHOI -79-98

\title{
TECTONICS OF THE WESTERN GULF OF OMAN
}

\author{
by
}

\author{
Robert S. White \\ and \\ David A. Ross
}

\begin{abstract}
WOODS HOLE OCEANOGRAPHIC INSTITUTION
Woods Hole, Massachusetts 02543
\end{abstract}

December 1979

TECHNICAL REPORT

Prepared for the Office of Naval Research under Contract N00014-74-C-0262; NR 083-004 and for the National Science Foundation under Grant 76-10417.

Reproduction in whole or in part is permitted for any purpose of the United States Govermment. In citing this report in a bibliography, the reference given should be to "Journal of Geophysical Research, Vol. 84, No. B7, July 10, 1979, pp. 3479$3489^{\prime \prime}$.

Approved for public release; distribution unlimited. Approved for Distribution: John I. Ewing, Chairman Department of Geology \& Geophysics 


\title{
Tectonics of the Western Gulf of Oman
}

\author{
ROBERT S. WHITE ${ }^{1}$ \\ Department of Geodesy and Geophysics, University of Cambridge, Madingley Rise, Cambridge, United Kingdom
}

DAVID A. Ross

Department of Geology and Geophysics, Woods Hole Oceanographic Institution, Woods Hole, Massachusetts 02543

\begin{abstract}
The Oman line, running northward from the Strait of Hormuz separates a continent-continent plate boundary to the northwest (Persian Gulf region) from an ocean-continent plate boundary to the southeast (Gulf of Oman region). A large basement ridge detected on multichannel seismic reflection and gravity profiles to the west of the Oman line is probably a subsurface continuation of the Musandam peninsula beneath the Strait of Hormuz. Collision and underthrusting beneath Iran of the Arabian plate on which this ridge lies has caused many of the large earthquakes that have occurred in this region. Convergence between the oceanic crust of the Arabian plate beneath the Gulf of Oman and the continental Eurasian plate beneath Iran to the north is accommodated by northward dipping subduction. A deformed sediment prism which forms the offshore Makran continental margin and which extends onto land in the Iranian Makran has accumulated above the descending plate. In the western part of the Gulf of Oman, continued convergence has brought the opposing continental margin of Oman into contact with the Makran continental margin. This is an example of the initial stages of a continent-continent type collision. A model of imbricate thrusting is proposed to explain the development of the fold ridges and basins on the Makran continental margin. Sediments from the subducting plate are buckled and incorporated into the edge of the Makran continental margin in deformed wedges and subsequently uplifted along major faults that penetrate the accretionary prism further to the north.
\end{abstract}

\section{INTRODUCTION}

Surveys made from RRS Shackleton [White and Klitgord, 1976; White, 1977a, 1978] show that subduction of the oceanic part of the Arabian plate in the Gulf of Oman beneath the continental Eurasian Plate to the north has caused considerable folding and thrusting of the sedimentary prism which forms the Makran continental margin of Pakistan and Iran. In the Persian Gulf and southern Iran, to the northwest of the Gulf of Oman, the continental part of the Arabian plate is in collision with the Eurasian plate (see inset Figure 1).

Separating the continent-continent plate boundary from the oceanic-continent plate boundaries is a major structural feature with a large strike-slip component that runs northward from the Strait of Hormuz and is commonly referred to as the Oman Line [Lees, 1928; Falcon, 1973, 1975; Farhoudi and Karig, 1977]. The Oman Line has been in existence since at least the Cretaceous, leading to strikingly different geology on either side of the line. Present day tectonic processes are also markedly different on each side of the Oman line, resulting in a belt of high seismicity in southern Iran to the west and the absence of all but a few earthquakes to the east [Nowroozi, 1976; Jacob and Quittmeyer, 1978].

The gravity anomaly map of the western Gulf of Oman and the Strait of Hormuz (Figure 2) shows a marked discontinuity at the position of the Oman line. Gravity contours tend to be aligned roughly east-west in the Makran region and be less negative in magnitude than the more confused pattern on the western side of the Oman line. The difference in the gravity field on either side of the Oman line may be caused by the contrast between the relatively thin oceanic lithosphere which probably lies beneath the accretionary sediment wedge of the

\footnotetext{
${ }^{1}$ Present address: Woods Hole Oceanographic Institution, Woods Hole, Massachusetts 02543 .
}

Copyright (c) 1979 by the American Geophysical Union.
Makran in the east and the thicker continental lithosphere beneath the Zagros in the west.

There are major differences in the geology across the structural discontinuity marked by the Oman line. To the west lie the Zagros Mountains, which have a thick Paleozoic, Mesozoic, and Tertiary sequence of sedimentary rocks that were deposited in a relatively shallow shelf sea. The entire sequence, above a décollement zone that lies in an Eocambrian salt layer, is folded into a simple series of anticlines trending NW-SE which date from the Pliocene and Pleistocene [Shearman, 1976]. Numerous diapiric salt domes intrude the eastern part of the Zagros Mountains [Falcon, 1974; Ala, 1974; Berberian, 1976]. Both the Zagros folds and the salt structures are truncated abruptly at the Oman line, as shown in Figure 1. The geological structure of the Makran, which lies to the east, is entirely different from the Zagros. The rocks are mainly Upper Cretaceous to Miocene sandstones and shales laid down in a marine trench and on the continental slope [Falcon, 1974; Berberian, 1976; Shearman, 1976]. This flysch sequence is greatly shortened by folding and thrusting in a north-south direction [Hunting Survey Corporation, 1960]. A highly contorted Jurassic and Cretaceous mélange and a belt of late Cretaceous to Tertiary volcanism lies to the north of the flysch belt, several hundred kilometers from the present coast.

Although the deep crustal movement on the Oman Line is predominantly strike-slip in a right lateral sense [Cornelius et al., 1973], the present day surface faulting is concentrated on the Zendan fault which displays a strong component of eastwest compression [Shearman, 1976]. The fault plane is a high angle thrust dipping eastwards. Compression has been active since the Mio-Pliocene, causing folding and thrust faulting on and to the west of the Zendan fault. Underthrusting of the continental material of the Arabian plate beneath the Eurasian plate north of the Strait of Hormuz is responsible for lateral compression across the Oman Line.

This paper discusses the deformation of the Makran continental margin and the western part of the Gulf of Oman and 


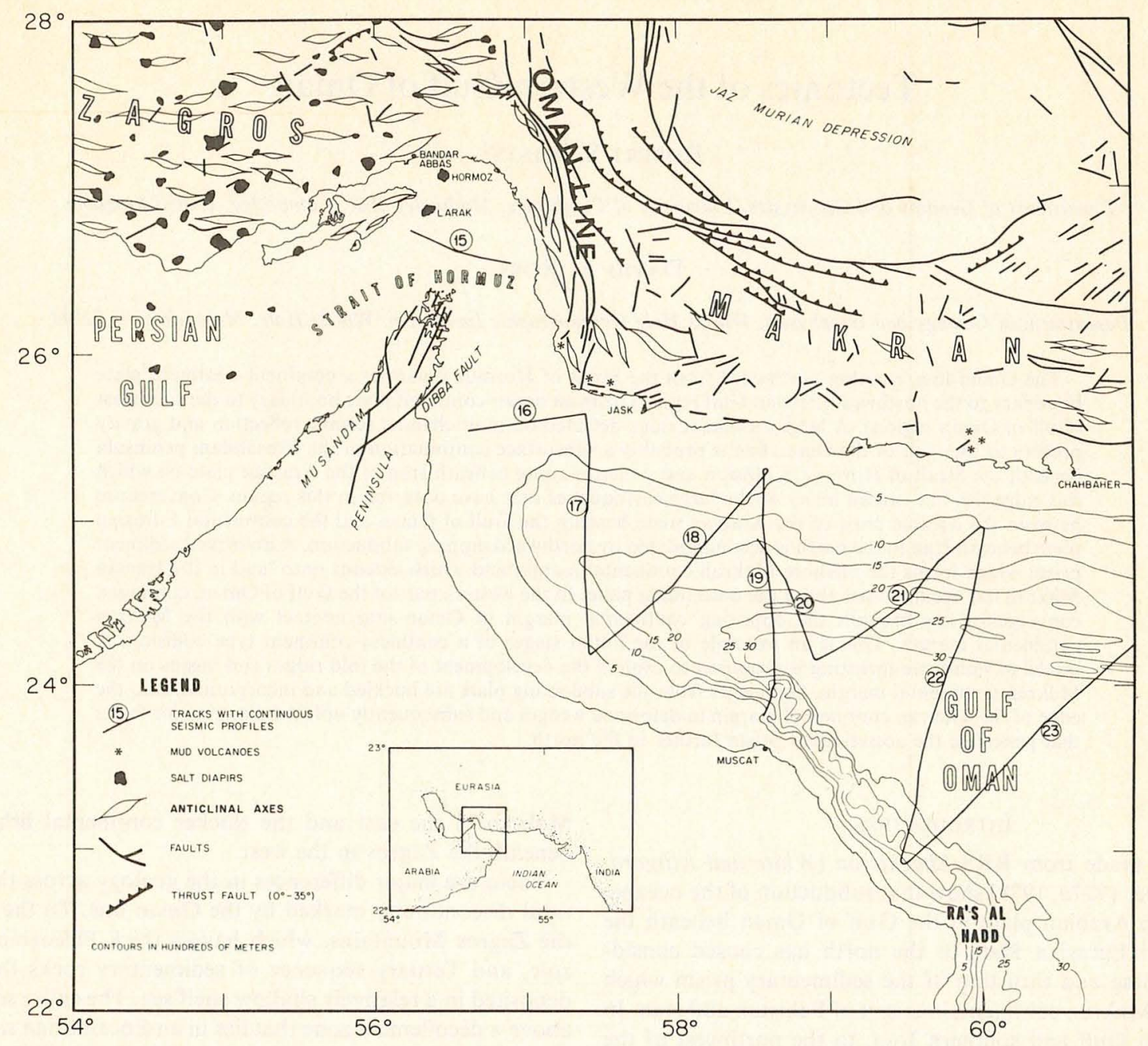

Fig. 1. Map showing location of tracks with continuous seismic profiles, gravity, magnetics and bathymetry in the western Gulf of Oman. Tracks numbered 15-19, inclusive, are multichannel seismic profiles taken by RV Atlantis II. Tracks labelled 20-23, inclusive, are single channel seismic profiles from RRS Shackleton. Inset shows location of area. Major geological trends indicated on land are taken from Hudson et al. [1954], Ahmed [1969], and Berberian [1976].

investigates the changes in structure which occur to the west where the opposing continental margin of Oman impinges on the Makran margin.

\section{Equipment}

The multi-channel seismic profiles obtained aboard RV Atlantis II (cruise 93, leg 18) in 1977 used a six-channel streamer with an array of Bolt airguns as the sound source. Individual trigger delays were applied to each gun such that the primary output pressure pulse of each gun added in phase, while the bubble pulses were largely cancelled. A firing interval of 30 secs was used, and a single channel real-time display recorded on a variable density Hewlett-Packard X-Y plotter (as shown in Figures 8, 9). The digitally recorded data were later filtered, deconvolved and stacked, then displayed in variable area format (as in Figures 3, 5, 6, 7). The six-channel array allowed significant enhancement through common depth point stacking only where the water depth was less than about $1 \mathrm{~km}$. Stacking velocities were calculated approximately once every 7 $\mathrm{km}$ from move-out across the multichannel array, supplemented by velocity determinations from disposable sonobuoys deployed over the flat-lying portions of sediment.

The seismic profiles taken by RRS Shackleton in 1975 used a single channel Geoméchanique streamer and a single airgun source fired once every $10 \mathrm{~s}$ (e.g., Figure 10) in the deep water of the Gulf of Oman; greater penetration and resolution was achieved with the single channel system than with the multichannel array largely because of the higher repetition rate. In the shallow water of the Strait of Hormuz, however, the processed multichannel records are consistently better.

Continuous gravity measurements were made aboard RV Atlantis II using a vibrating string gravimeter and aboard RRS Shackleton using a LaCoste-Romberg gravimeter. The total field magnetic intensity was sampled with a Varian magnetometer. Continuous 3.5 and $12 \mathrm{kHz}$ echo-sounding profiles were also recorded. Navigation was by a combination of a Magnavox Satellite Navigator, Decca and Doppler log.

\section{West OF THE OMAN LINE}

\section{Northern Continuation of the Musandam Peninsula}

The Musandam, or Arabian, Peninsula projects some 250 $\mathrm{km}$ northward from the Arabian mainland (Figure 1). To the west lies the Persian Gulf, a shallow sea underlain by a thick sequence of Paleozoic and Mesozoic limestones and dolomites [Mina et al., 1967; D. A. Ross et al. manuscript in preparation, 1979]. The narrow Strait of Hormuz separates the Musandam 


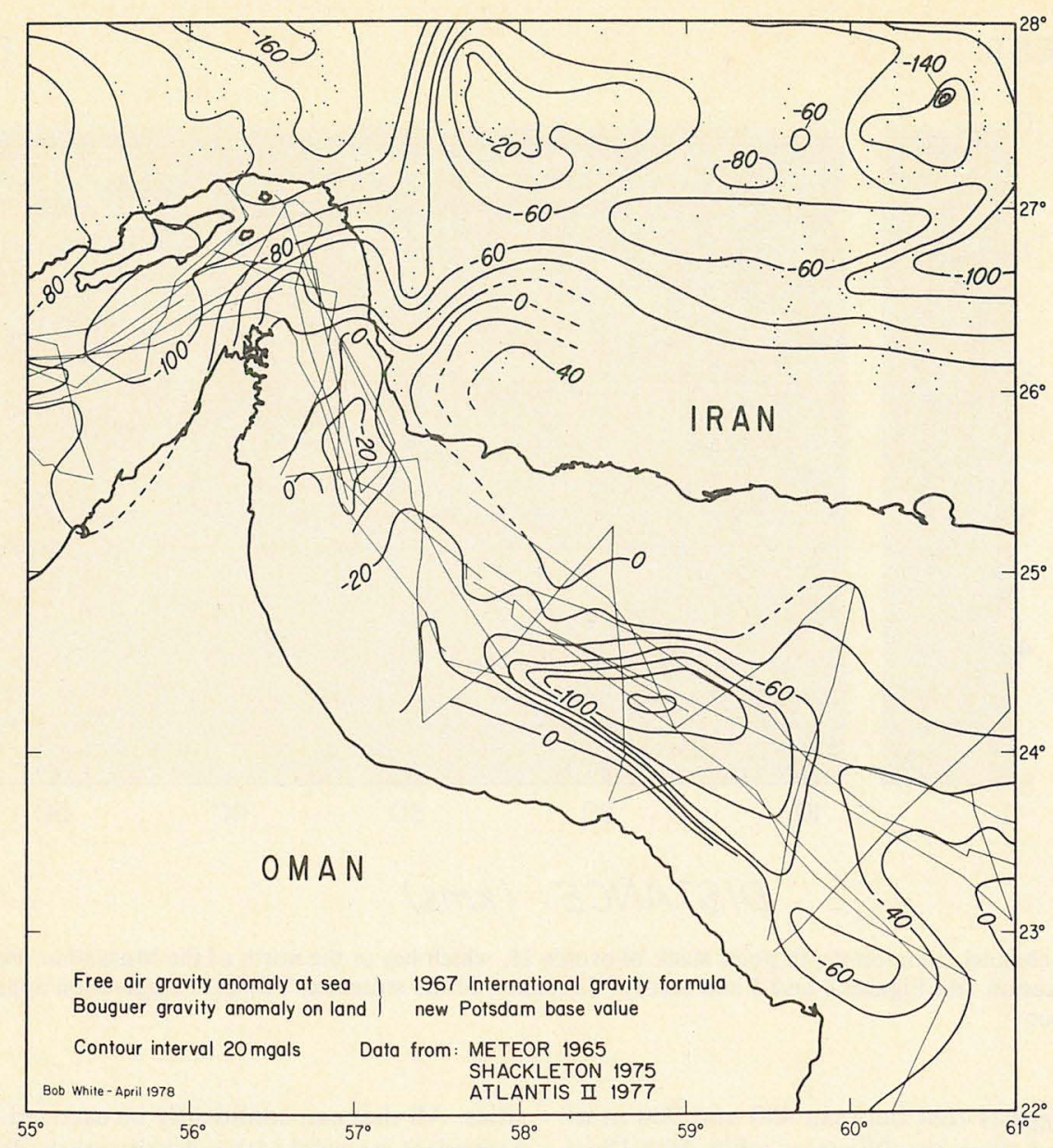

Fig. 2. Gravity anomaly map of the western Gulf of Oman and the Strait of Hormuz. Free-air gravity anomalies used at sea, Bouguer gravity anomalies on land. Gravity values at sea are from cruises by RV Meteor (1965), RRS Shackleton (1975), and RV Atlantis II (1977). Anomalies were obtained using the 1967 International Gravity Formula with earth flattening of $1 / 298.25$ and a Potsdam base value of 981.260 gal. Location of gravity measurements shown as thin lines at sea and as dots on land. Contour interval 20 mgals.

Peninsula from Iran to the north; to the southeast is the Gulf of Oman, which rapidly deepens to an abyssal plain nearly $3 \frac{1}{2}$ $\mathrm{km}$ deep. Multi-channel reflection profiles were taken through the Strait of Hormuz and down the eastern side of the Musandam Peninsula, but unfortunately the streamer became entangled several times with fishermen's nets in the shallow water and only two lines (labelled 15 and 16 on Figure 1), yielded good data.

Immediately apparent on the east-west seismic profile in the Strait of Hormuz (Figure 3 ) is a large basement ridge which is completely buried by sediment. Sediment layers onlap the basement from both sides. To the west of the ridge the sediment horizons are horizontal, while on the other side they dip gently to the east.

The basement ridge is probably a northward continuation of the Musandam Peninsula. Structurally, the rocks outcropping on the peninsula belong to a $3400 \mathrm{~m}$ thick unit, known as the Ruus al Jibal unit, which was thrust a short distance from the northeast in Neogene times. The thrust consists almost entirely of shallow water marine limestones, with some marls and dolomites, ranging in age from Permian to Lower Cretaceous [Hudson et al., 1954; Hudson, 1960; Alleman and Peters, 1972; South, 1973]. Beneath the Ruus al Jibal thrust unit are Jurassic and Lower Cretaceous tuffs and radiolarian cherts of the
Hawasina complex, which outcrops extensively further south in Oman [Glennie et al., 1973]. The overriding thrust sheet represents a near-edge slice of Arabian platform sediments.

The morphology of the buried basement ridge recorded on our seismic profile (Figure 3 ) duplicates that of the Ruus al Jibal unit seen on land. In an east-west cross section, the western front of the Ruus al Jibal thrust unit consists of very steeply dipping, vertical or even overturned strata, while the eastern limb has a small easterly dip. Similarly, the buried basement has a flat top, probably accentuated by marine erosion prior to burial. The western edge of the buried ridge descends in near-vertical steps, while the eastern side is smoother and less steep (Figure 3). There is some irregularity in the shape of the western edge, as is demonstrated by the presence of abundant diffractions in the seismic section which are probably caused by basement projections off the line of the profile. The western edge of the Ruus al Jibal unit on land is also dissected by a number of wadis and by minor thrusts and folds.

Further reasons for assuming that the basement ridge is a northward continuation of the thrust sheet outcropping on the Musandam Peninsula are that the thrust plane beneath the Ruus al Jibal unit dips gently northward and that relatively rapid rates of submergence of the peninsula have been re- 


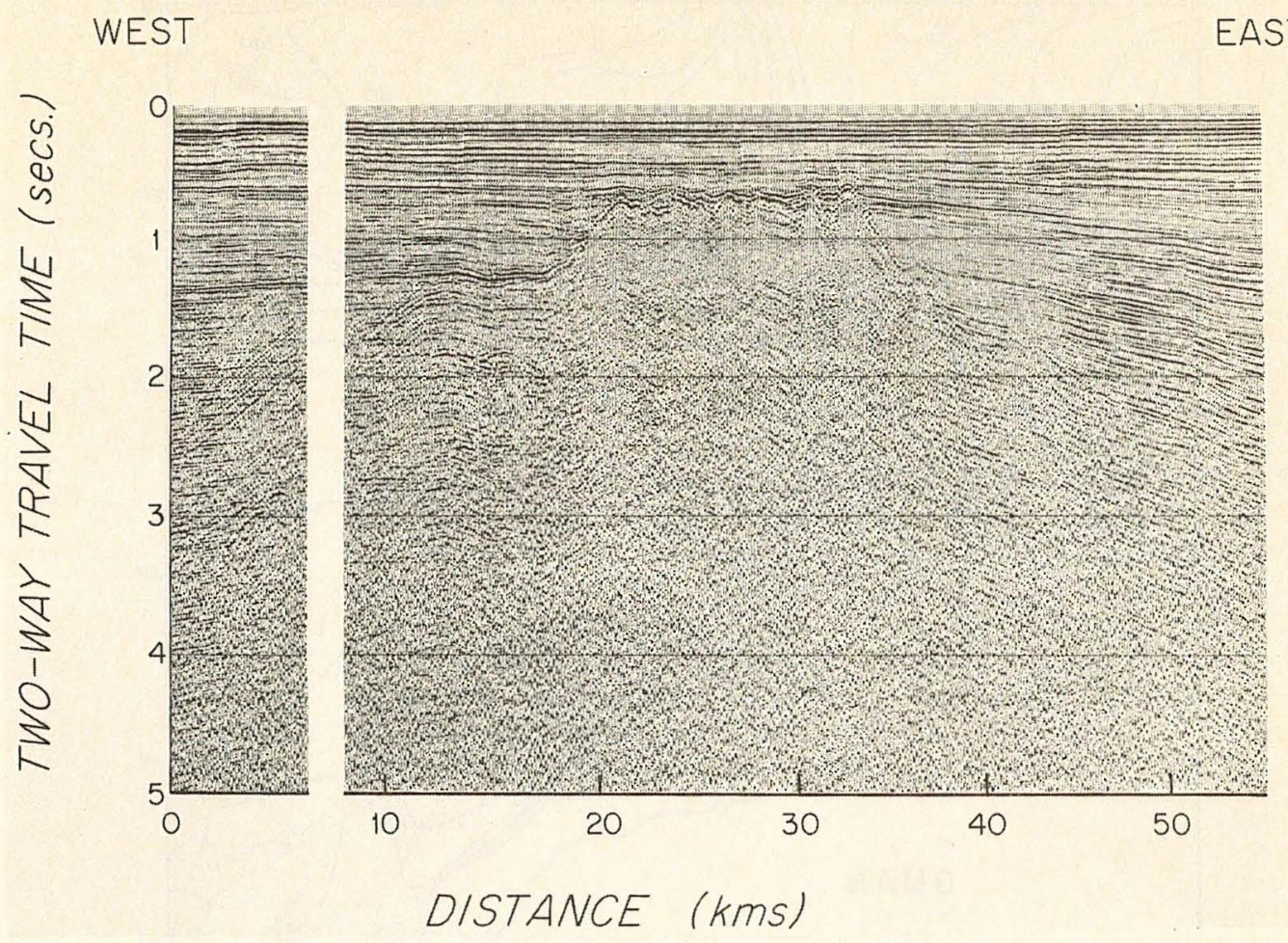

Fig. 3. Six channel common-depth point stack of profile 15, which lies to the north of the Musandam Peninsula. See Figure 1 for location and Figures 4 and 5 and text for discussion of the structure. Vertical exaggeration approximately 9 times at sea floor.

ported. Lees [1928] suggests that between 450 and $900 \mathrm{~m}$ of depression has occurred since the Pliocene, while Vita-Finzi (in Cornelius et al. [1973]) has recorded more than $60 \mathrm{~m}$ subsidence on the northern and eastern coasts of the Musandam Peninsula in the last 10,000 years.

Magnetic and gravity measurements recorded simultaneously with the seismic profile support the interpretation of the basement ridge as part of the carbonate succession of the Ruus al Jibal thrust sheet. The absence of a magnetic high associated with the basement ridge (Figure $4 a$ ) suggests that it is not igneous or metamorphic in origin. There is, however, a free air gravity high located over the buried basement (Figure $4 b$ ). Unfortunately, the regional gravity gradient is locally so great that it is difficult to assess the magnitude of the residual gravity anomaly due to the basement ridge alone. An attempt to subtract the regional gravity trend was therefore made by assuming that it could be represented by a simple, linear gradient, as shown in Figure $4 b$. The resultant residual gravity anomaly has a maximum amplitude of about 35 milligals along the line of profile 5 (Figure $4 c$ ).

The theoretical two dimensional gravity anomaly was calculated using the basement shape observed on the seismic profile (as shown in Figure $4 d$ ). Densities of the sedimentary prism were derived from measured sediment compressional wave velocities using the empirical velocity versus density correlation of Gardner et al. [1974]. As shown in Figure 4c, a basement density of $2.55 \mathrm{~g} / \mathrm{cc}$ gives a good match to the observed residual anomaly, although a density of $2.65 \mathrm{~g} / \mathrm{cc}$, which is typical of limestones, yields an anomaly which is about 10 milligals too high. However, as reference to Figure 2 demonstrates, the regional gradient is insufficiently well known, particularly in this area which is close to the continental margin and exhibits steep gradients, to be able to define the residual anomaly precisely enough to discriminate between these den- sities. All that can confidently be asserted is that the basement comprises material with a density markedly higher than that of the mantling sediment and that the magnetic and gravity anomalies are consistent with a carbonate basement. The gravity anomaly map of the area (Figure 2 ) shows that the gravity high above the submerged basement ridge can be traced continuously from the Musandam Peninsula.

The arguments cited above indicate that the Musandam Peninsula extends northward beneath the Strait of Hormuz, though our seismic profile only reveals the uppermost part of it. Collision and underthrusting of this promontory of Arabia beneath mainland Iran may be responsible for the large number of earthquakes which occur in this vicinity. Fault plane solutions for these earthquakes consistently indicate thrusting with a north-south slip vector (D. P. McKenzie, personal communication, 1977). Morris [1979] also cites the character of aeromagnetic anomalies as indicative of underthrusting of Arabia in this region.

\section{Eastern Margin of the Musandam Peninsula}

The other multichannel seismic profile adjacent to the Musandam Peninsula (line 16, Figure 5), runs in an easterly direction across the southeastern entrance to the Strait of Hormuz. At the easternmost end the profile crosses into the folded zone, discussed in more detail below, which lies along the whole of the eastern margin of Iran and Pakistan (beyond $62 \mathrm{~km}$ on Figure 5).

Near the middle of the line (from 20 to $50 \mathrm{~km}$ on Figure 5), the roughly flat-lying sedimentary sequence is cut by many high angle faults. An enlargement of part of this central section, illustrated in Figure 6, shows that some of the faults, which are still active, extend from the present-day seabed to as deep in the section as it is possible to resolve (e.g., the fault at $29 \mathrm{~km}$ on Figure 6). Other faults only displace horizons at 
depth and die out some distance beneath the seabed (e.g., the faults near 35 and $37 \mathrm{~km}$ on Figure 6). The faults which terminate well below the seabed probably ceased to be active before deposition of the overlying undisturbed sediment. In general, the uppermost $2 \mathrm{~km}$ of the seismic section exhibits large blocks up to several kilometers in width of undisturbed, or at most, gently tilted sediment while the deeper material is considerably more disturbed by faulting.

The western end of line 16 (between 0 to $20 \mathrm{~km}$ on Figure 5), where it approaches the coast of the Musandam Peninsula, crosses a thick pile of gently dipping, undisturbed sediment. Seismic velocity measurements from a sonobuoy profile indicate that the sediment is over $4 \mathrm{~km}$ thick. Penetration is insufficient to reach basement except at the very westernmost end of the profile, where a strong reflector at a depth of about $2.2 \mathrm{~s}$ two-way travel time (approximately $2 \frac{1}{2} \mathrm{~km}$ ), can be seen dipping steeply eastwards away from the Musandam Peninsula. This horizon may represent the top of the Cretaceous rocks which outcrop on the Musandam Peninsula and continue northward beneath the Strait of Hormuz, as discussed above.

\section{EAST OF THE OMAN LINE}

\section{The Oman Continental Margin}

To the east of $58^{\circ} \mathrm{E}$ the continental margin off the northeastern coast of Oman drops steeply down to the Gulf of Oman abyssal plain at a depth of $3340 \mathrm{~m}$. On shore the land rises to rugged mountains over $2000 \mathrm{~m}$ in height. Tectonically, this is probably a passive plate margin with no differential movement between the continental mainland of Oman and the oceanic crust which underlies the Gulf of Oman.

In places the continental slope is so steep that the sediments have become unstable and have moved downslope in huge gravity slumps with morphology similar to slumps reported elsewhere [Heezen and Drake, 1964; Roberts, 1972]. Seismic profile 19 (illustrated in Figure 7), which runs northward from the Oman coast near Muscat, crosses a number of such slumps. This single profile is insufficient to delineate accurately the dimensions of the features, but it is apparent that the slumps are of the order of $10 \mathrm{~km}$ long and several hundred meters thick. The average slope of the slumped margin is about $5^{\circ}$. Individual slumps retain coherent reflectors within them, and the toe of buckled sediment at the front of the most recent slumps is still visible slightly above the level of the abyssal plain (at $127 \mathrm{~km}$ on Figure 7). Continued sedimentation progressively buries the toe. In the uppermost kilometer of sediment beneath the abyssal plain on profile 19 an interface can be traced diagonally across the sediments separating the deformed toes of former slumps from the gently dipping sediments which have buried them (123-127 km on Figure 7).

In the western part of the Gulf of Oman, convergence between the Arabian plate and the Eurasian plate has brought the continental margin of Oman into contact with the opposing Makran continental margin of Iran. The Makran continental margin is a deformed accretionary sediment prism formed by northward subduction of the oceanic crust underlying the Gulf of Oman [White and Klitgord, 1976; White, 1979]. Along most of the Makran continental margin undisturbed flat-lying sediments of the Gulf of Oman abyssal plain deposited on the Arabian oceanic plate lie south of the folded belt. The outer edges of the Makran and Oman continental margins have only come into contact in the westernmost part of the Gulf of Oman in geologically recent times due to continued convergence.

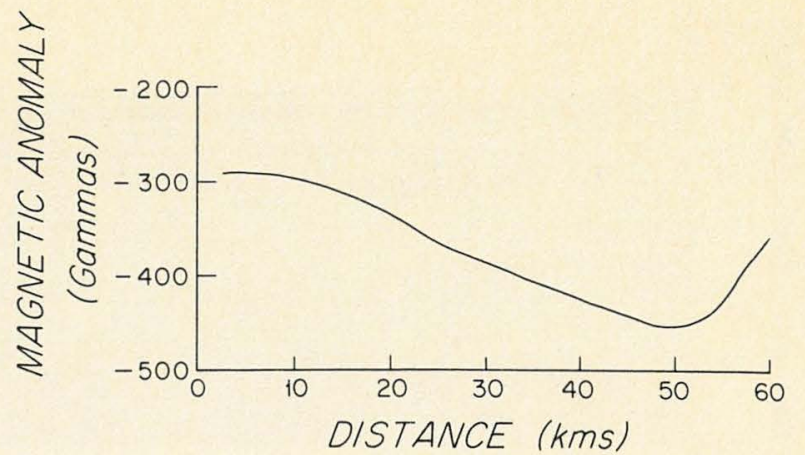

a.
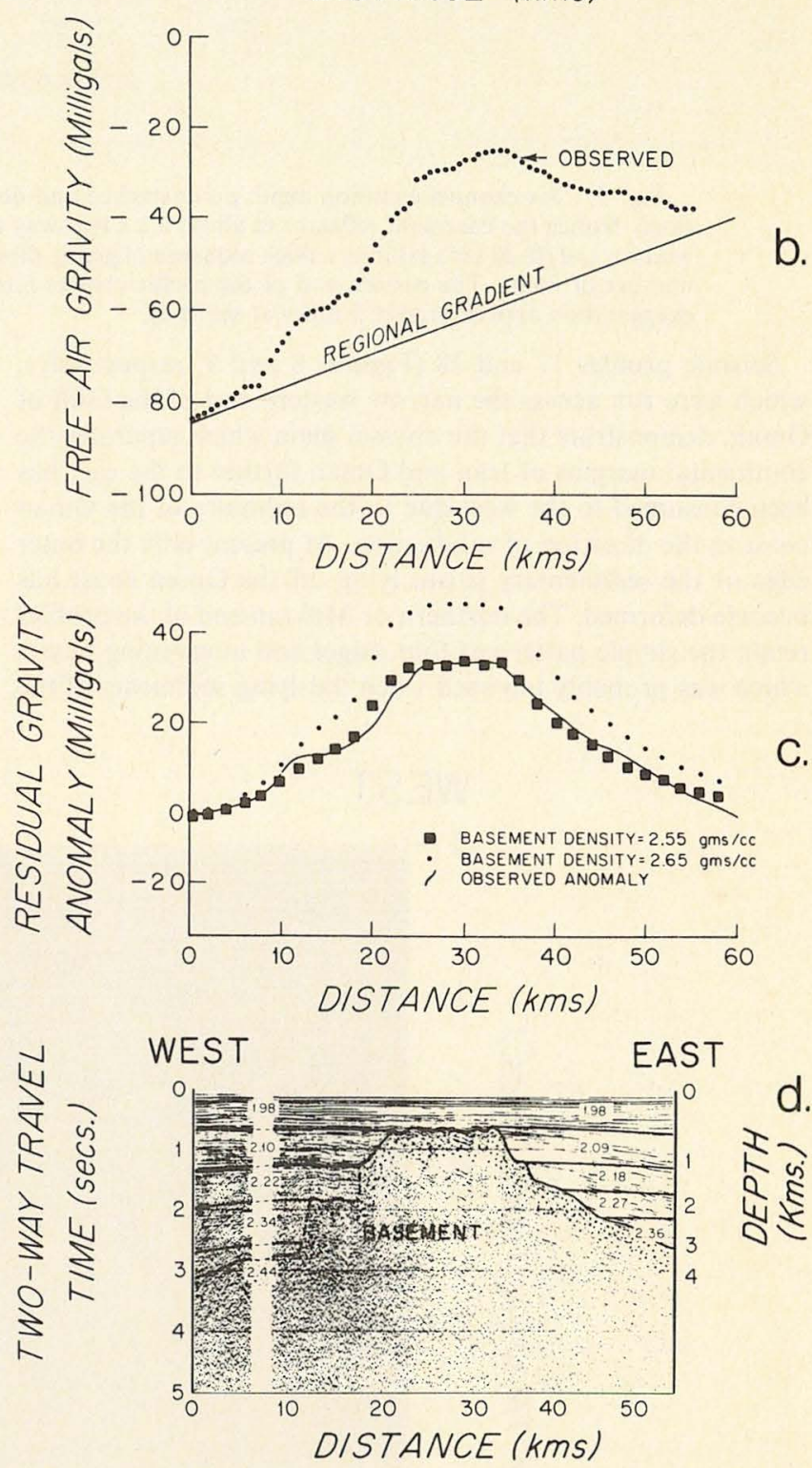

Fig. 4. (a) Total field magnetic anomaly along profile 15 after subtraction of the International Geomagnetic Reference Field. Note the lack of any anomaly associated with the prominent basement ridge. $(b)$ Observed free-air gravity anomaly along profile 15 , with the simple linear regional gravity gradient which was subtracted to give the residual gravity anomaly shown in Figure $4 c$. (c) Residual free-air gravity anomaly (solid line) along profile 15 after subtraction of the linear regional gradient; squares show theoretical two-dimensional anomaly produced by the density model in Figure $4 d$ with basement density of $2.55 \mathrm{~g} / \mathrm{cc}$; dots show the theoretical anomaly with basement density of $2.65 \mathrm{~g} / \mathrm{cc}$. (d) Density model of profile 15 used to construct theoretical gravity anomalies illustrated in Figure $4 c$. Note that the interfaces at the eastern end are lines of equal density due to compaction and lithification and so are less inclined than the sediment layering. Vertical exaggeration approximately 9 times at sea level. 


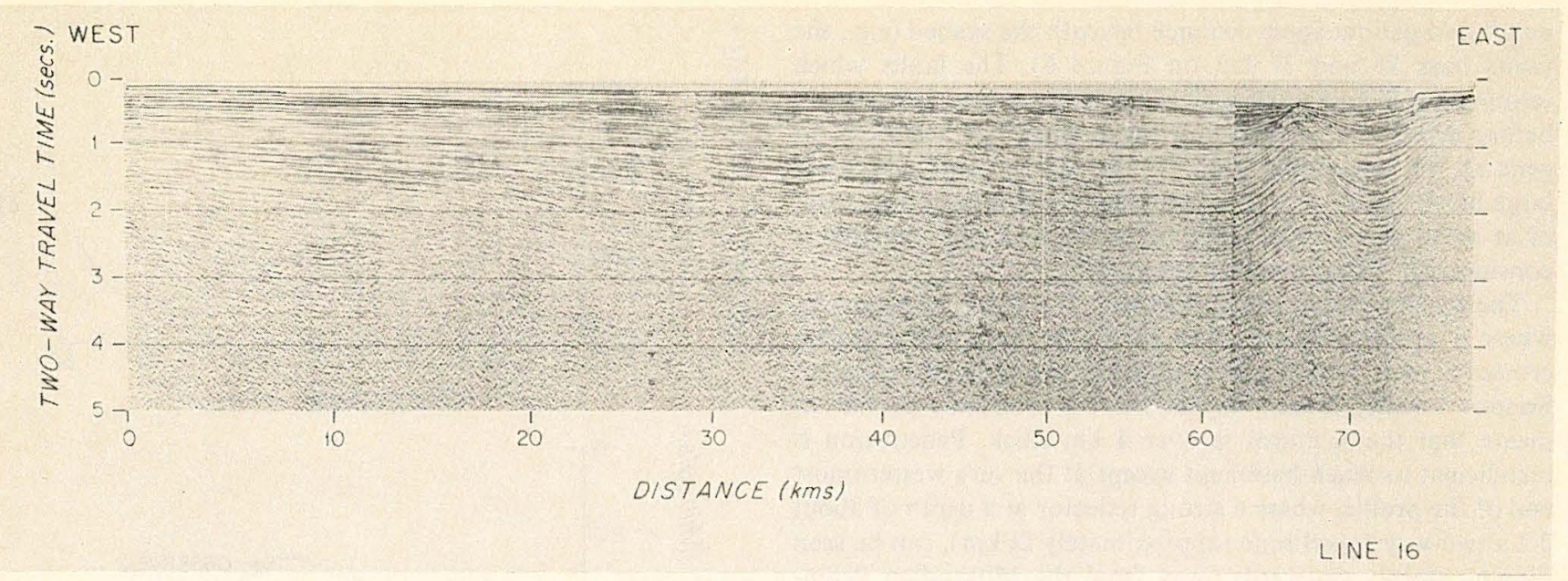

Fig. 5. Six channel common depth point stacked and deconvolved seismic profile along line 16 (see Figure 1 for location). Notice the basement reflector at about $2.2 \mathrm{~s}$ two-way travel time at $0 \mathrm{~km}$ distance which dips steeply eastward. The western end $(0-20 \mathrm{~km})$ exhibits a thick sequence of gently dipping sediments, while the middle section $(20-50 \mathrm{~km})$ is cut by a number of faults. The eastern end of the profile crosses into the folded belt of the Makran continental margin. Vertical exaggeration approximately 5 times at sea level.

Seismic profiles 17 and 18 (Figures 8 and 9, respectively), which were run across the narrow western end of the Gulf of Oman, demonstrate that the abyssal plain which separates the continental margins of Iran and Oman further to the east has been consumed to the west due to the obliquity of the Oman coast to the direction of subduction. At present only the outer edge of the sedimentary prism lying off the Oman coast has become deformed. The northern or Makran end of the profiles retain the simple pattern of fold ridges and intervening basins which was probably imposed when flat-lying sediments of the abyssal plain lay to the south and were being subducted in this area. An example of the open ridge and basin style of deformation which results where flat-lying sediments lie beyond the continental margin is shown in Figure 10 (profile 22 in Figure 1 ); more seismic profiles further to the east which exhibit the same features are illustrated in Figure 2 of White and Klitgord [1976]. The modes of formation of these fold ridges are discussed in more detail later in this paper.

Where the two continental margins have started to collide, deformation has begun to spread southward into the sediment

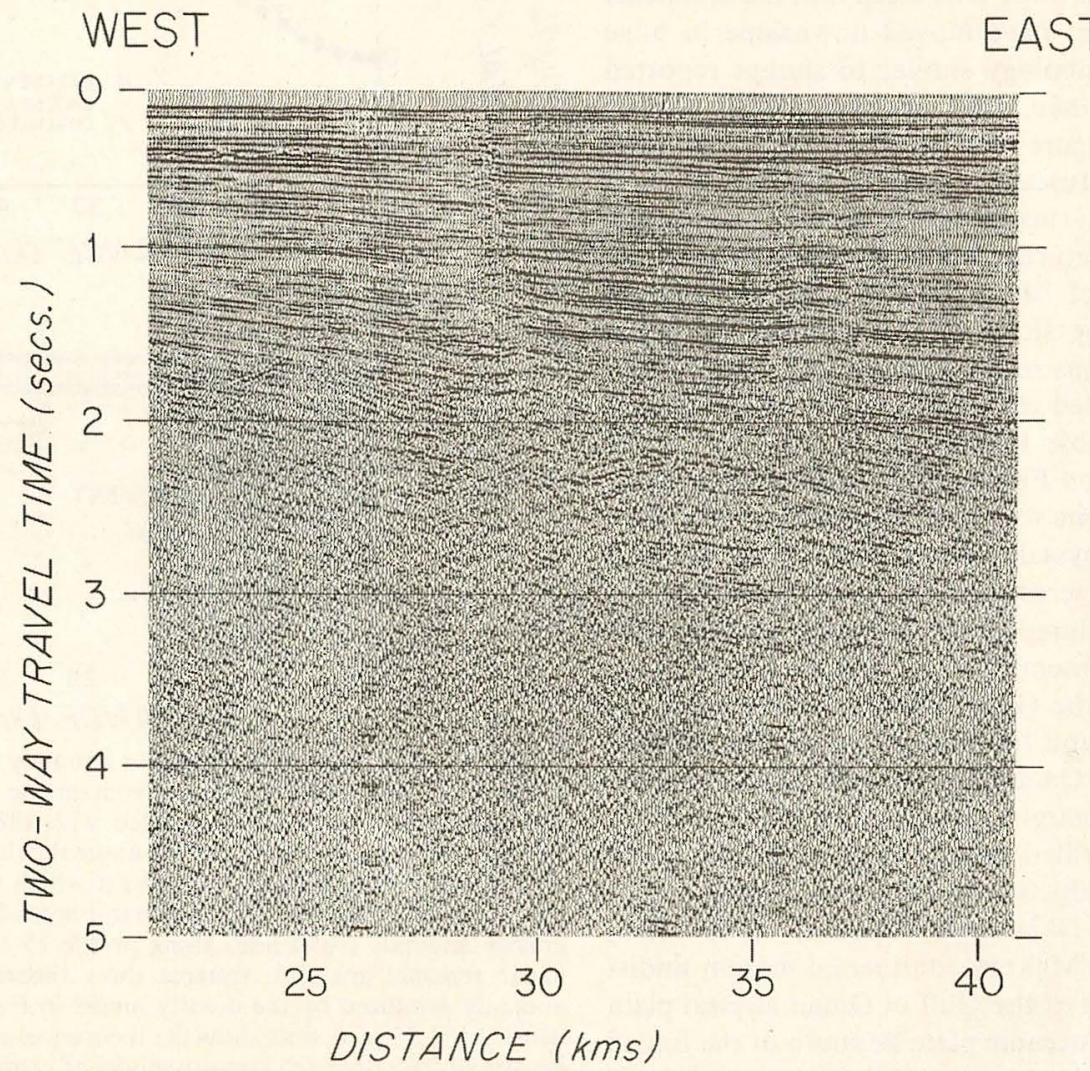

Fig. 6. Enlargement of part of line 16 illustrated in Figure 5. Notice the fault at $29 \mathrm{~km}$ which penetrates to the sea floor and the fault near $35 \mathrm{~km}$ which terminates at a depth of about $0.6 \mathrm{~s}$ two-way travel time beneath the sea floor. 


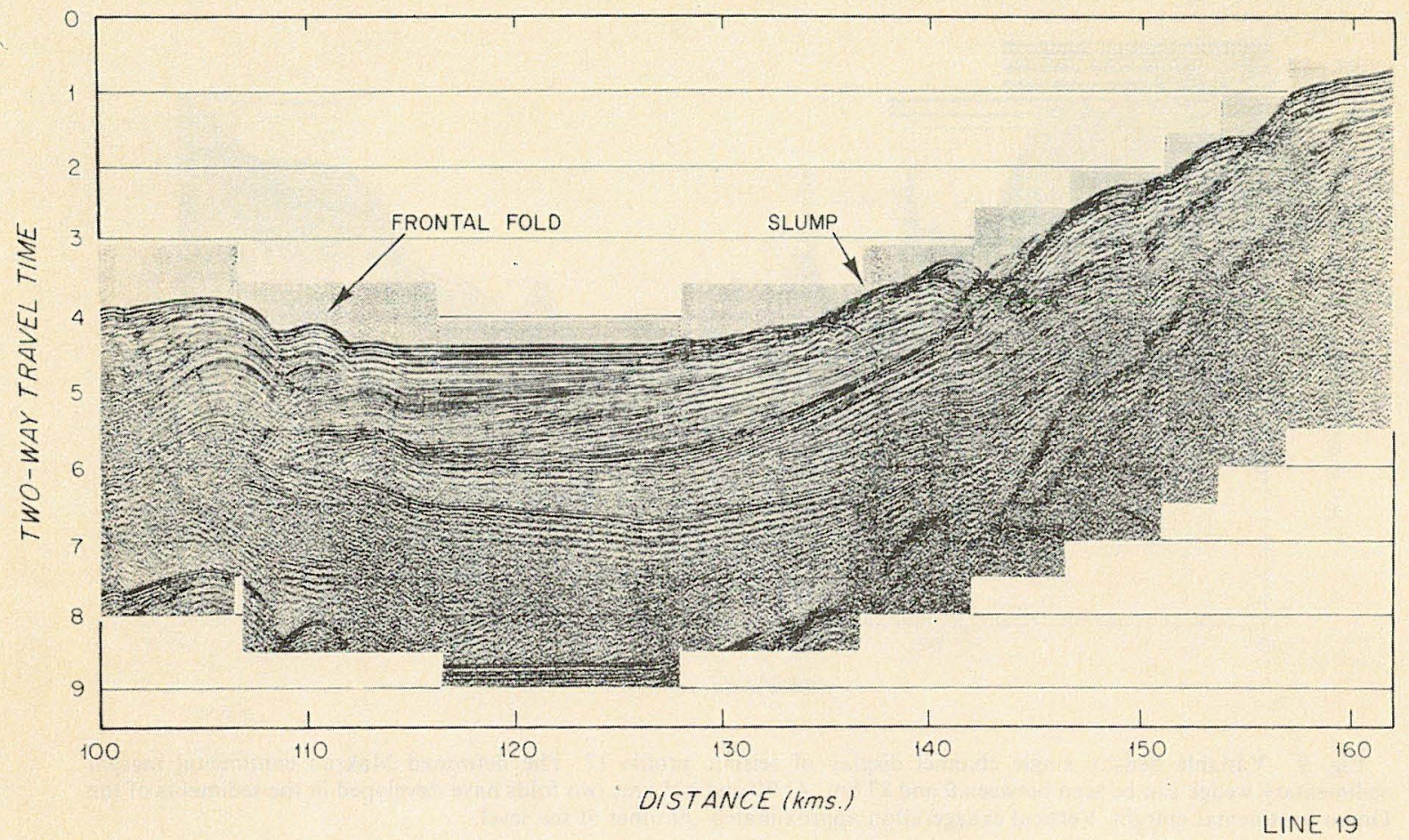

Fig. 7. Southern part of profile 19, across the Oman continental margin (see Figure 1 for location). Notice the large gravity slumps from 130 to $155 \mathrm{~km}$, and the partly buried toe at $127 \mathrm{~km}$. Frontal folds of Makran fold belt are seen at 113 $\mathrm{km}$. Vertical exaggeration approximately 5 times at sea bed.

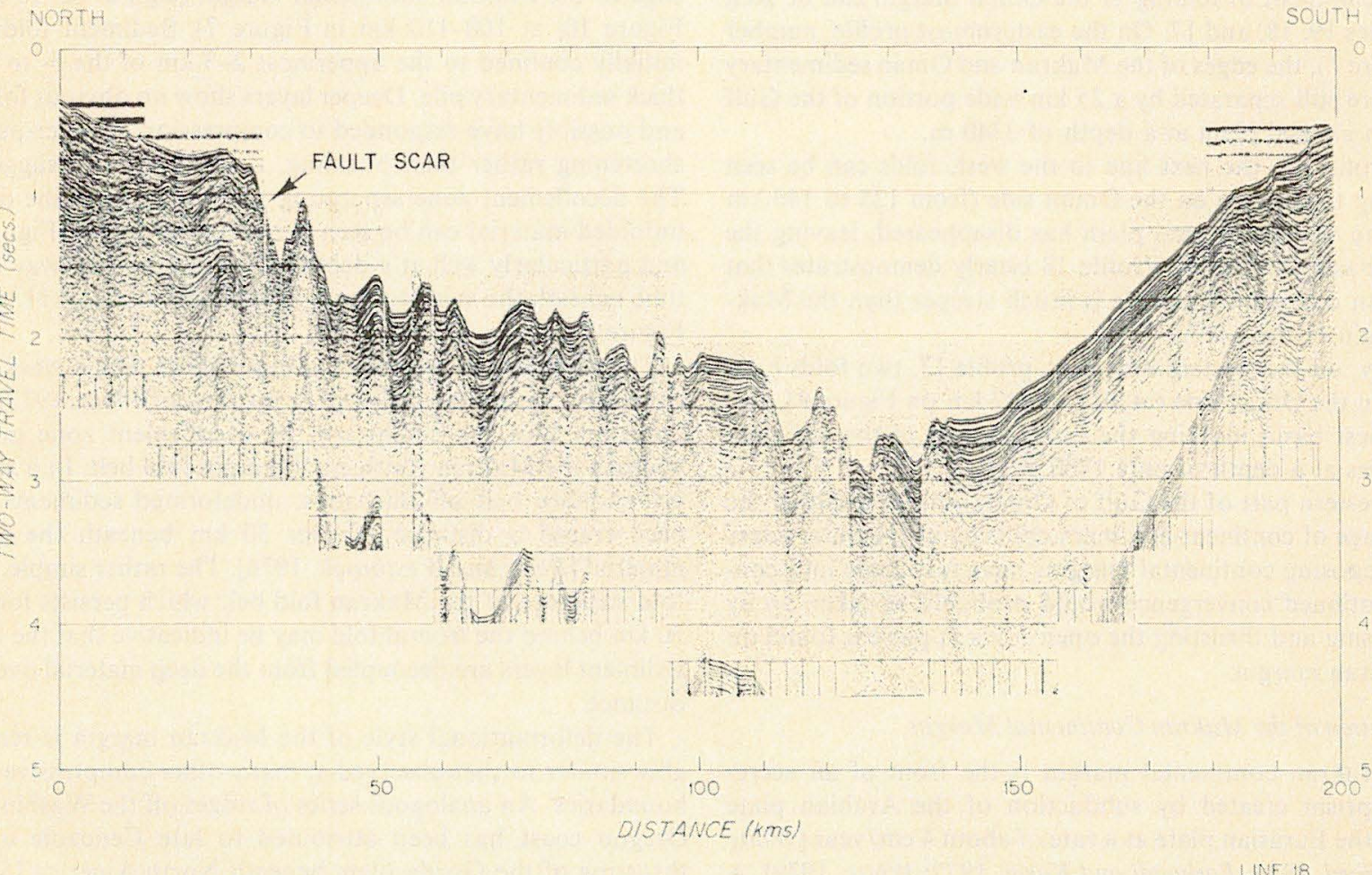

Fig. 8. Variable density single channel display of seismic profile 18 showing sediment prisms of the Makran and Oman continental margins in collision. The ridge and trough topography of the Makran fold belt can be seen between 0 and 125 $\mathrm{km}$, and the much steeper slope off the coast of Oman from 125 to $200 \mathrm{~km}$. Vertical exaggeration approximately 30 times at sea level. 


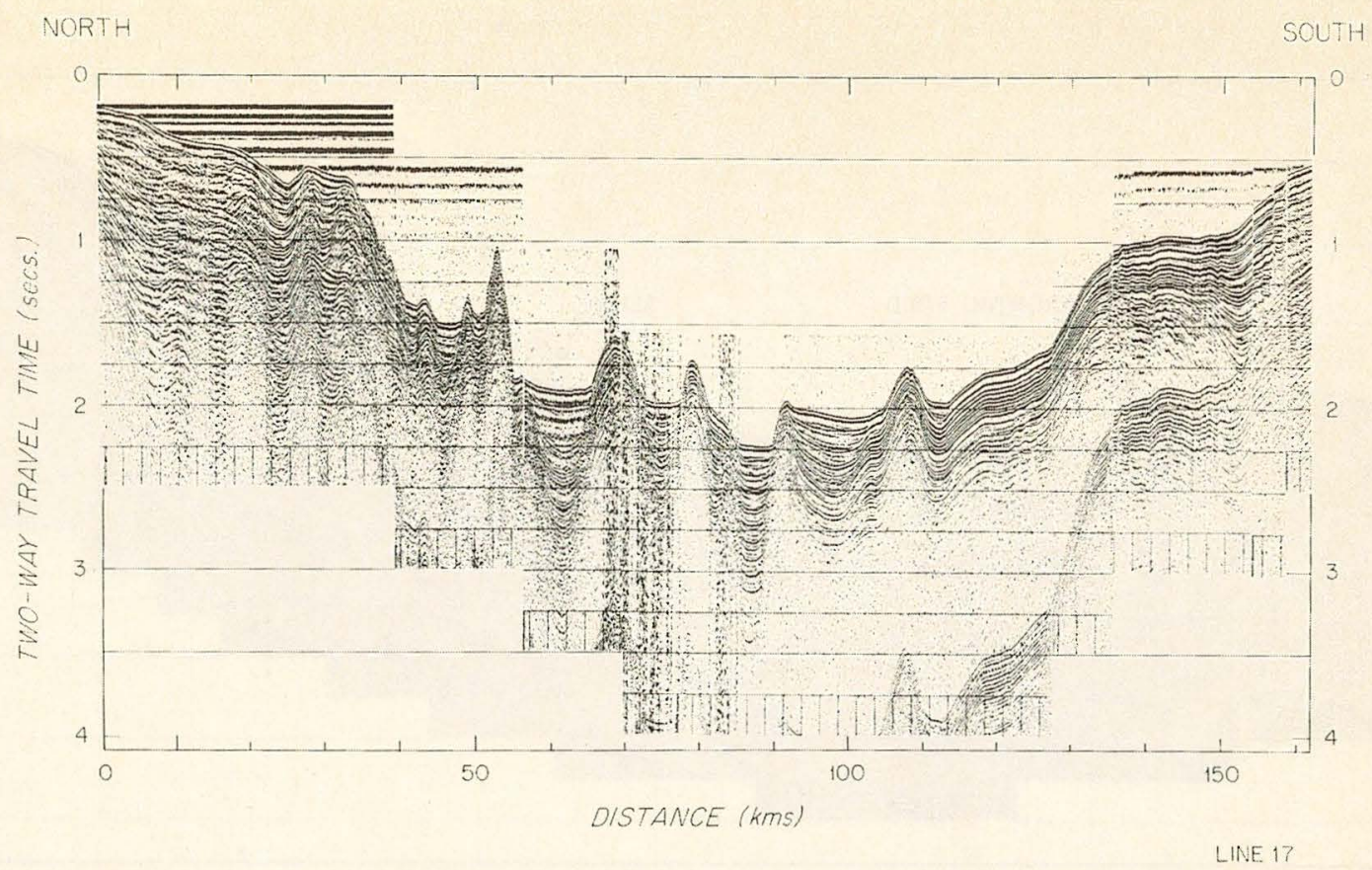

Fig. 9. Variable density single channel display of seismic profile 17. The deformed Makran continental margin sedimentary wedge can be seen between 0 and $87 \mathrm{~km}$. At 90 and $107 \mathrm{~km}$, two folds have developed in the sediments of the Oman continental margin. Vertical exaggeration approximately 30 times at sea level.

pile off the coast of Oman (e.g., 90-120 km on Figure 9, 125$140 \mathrm{~km}$ on Figure 8). The upper part of the sediment pile has become contorted into open folds with a wavelength of about $10 \mathrm{~km}$ and maximum heights of the order of $800 \mathrm{~m}$. A progressive development in folding of the Oman margin can be seen on profiles 19,18 , and 17 . On the easternmost profile, number 19 (Figure 7), the edges of the Makran and Oman sedimentary prisms are still separated by a $25 \mathrm{~km}$ wide portion of the Gulf of Oman abyssal plain at a depth of $3340 \mathrm{~m}$.

On profile 18 , the next line to the west, folds can be seen beginning to develop on the Oman side (from 125 to $140 \mathrm{~km}$ on Figure 8). The abyssal plain has disappeared, leaving the deepest basin at $2250 \mathrm{~m}$. Profile 18 clearly demonstrates that the Oman continental margin is much steeper than the Makran margin to the north.

Finally, on the westernmost line, profile 17, two folds have grown on the Oman side (at 90 and $107 \mathrm{~km}$ on Figure 9), and the deepest basin marking the former edges of the sediment prisms lies at a depth of only $1700 \mathrm{~m}$.

The western part of the Gulf of Oman is an example of the initial stage of continent-continent collision as the outer edges of the opposing continental margins have just come into contact. Continued convergence would probably be taken up by compressing and thrusting the open folds at present found on the Makran margin.

\section{Deformation of the Makran Continental Margin}

The Makran continental margin is the front of an accretionary prism created by subduction of the Arabian plate beneath the Eurasian plate at a rate of about $4 \mathrm{~cm} /$ year [White and Klitgord, 1976; Farhoudi and Karig, 1977; White, 1979]. A strikingly consistent pattern of lineated fold ridges and basins is present along the entire Makran margin, from the easternmost profile at $64^{\circ} \mathrm{E}$ shown in Figure 2 of White and Klitgord [1976] to the westernmost lines at $57^{\circ} \mathrm{E}$ discussed above (Fig- ures $8,9,10)$. The structural discontinuity of the Oman line forms the western limit to this simple style of deformation.

The flat-lying deposits presently found in the Gulf of Oman abyssal plain are deformed into frontal folds at the southern edge of the Makran continental margin (e.g., at $80-90 \mathrm{~km}$ in Figure 10; at $100-110 \mathrm{~km}$ in Figure 7). Sediment folding is initially confined to the uppermost $2-3 \mathrm{~km}$ of the $5-$ to $6-\mathrm{km}$ thick sedimentary pile. Deeper layers show no obvious folding, and possibly have responded to compression by layer-parallel shortening rather than buckling, as White [1977] suggested. The décollement zone separating the folded from the deeper unfolded material can be seen in the frontal fold in Figure 10, and particularly well at a depth of about $6.3 \mathrm{~s}$ two-way travel time beneath the southernmost frontal fold at about $113 \mathrm{~km}$ in Figure 7.

The décollement zone probably coincides with a weak layer caused by abnormally high pore pressures [White, 1977]. It is uncertain how far northward the décollement zone extends beneath the Makran continental margin fold belt. In a similar accretionary belt off Barbados, undeformed sediments have been traced a distance of over $30 \mathrm{~km}$ beneath the folded material [Peter and Westbrook, 1976]. The rather simple, open fold structure of the Makran fold belt which persists for over $50 \mathrm{~km}$ behind the frontal fold may be indicative that the upper sediment layers are decoupled from the deep material over this distance.

The deformational style of the Makran margin is remarkably similar to that observed at many other compressive plate boundaries. An analogous series of ridges off the WashingtonOregon coast has been attributed to late Cenozoic underthrusting of the Gorda plate beneath North America [Silver, 1969, 1971; Kulm and Prince, 1973; Carson et al., 1974; Kulm and Fowler, 1974], and similar deformed sediment piles have been reported in the Carribean [Westbrook, 1975]. Well-defined ridge and trough topography is apparent on published 


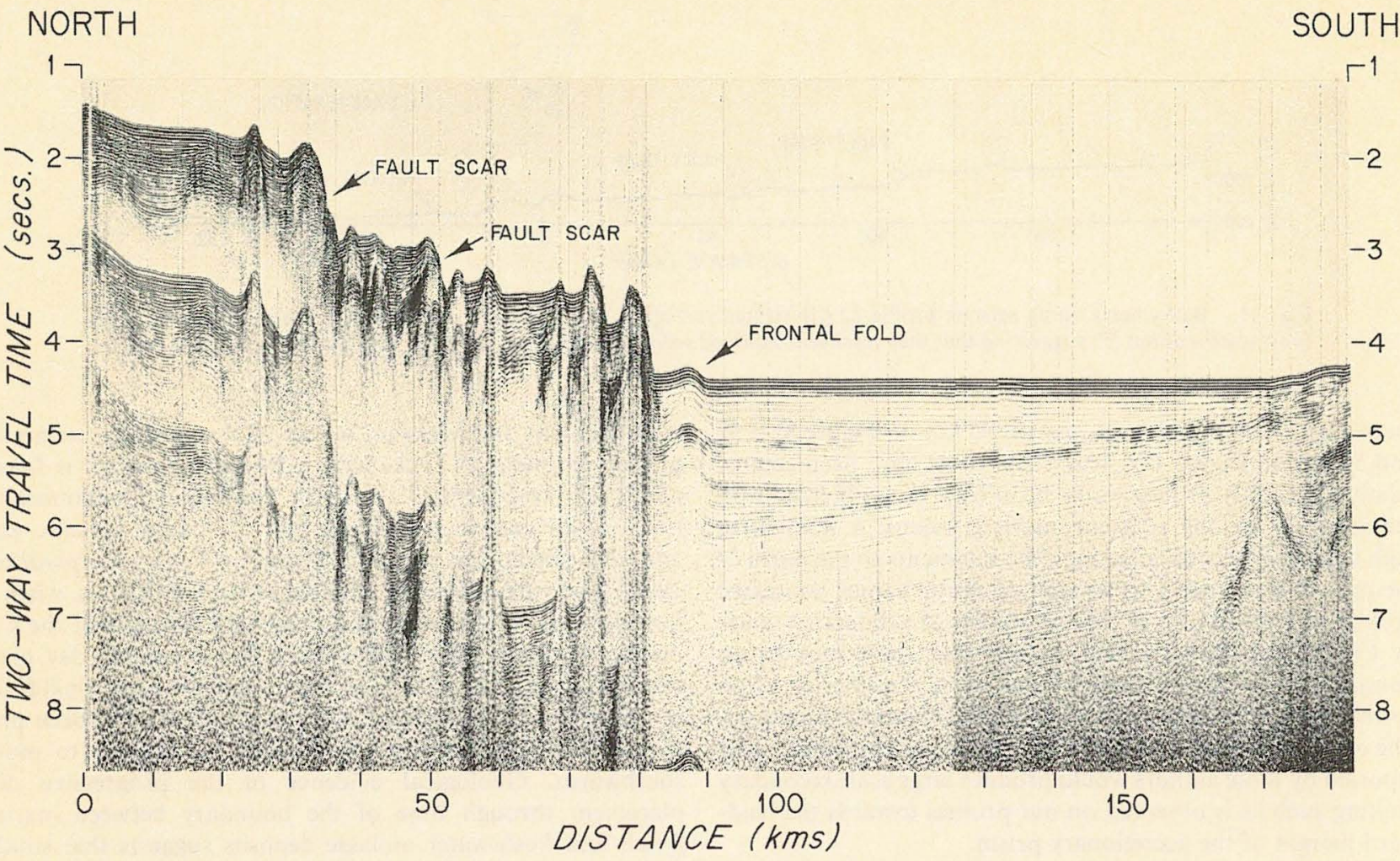

Fig. 10. Variable density single channel display of seismic profile 22 (see Figure 1 for location). Flat-lying deposits of the Gulf of Oman abyssal plain are initially deformed at the frontal fold and then incorporated into the accretionary prism of the Makran continental margin by a series of imbricate thrust faults. Compare this profile with the simplified model in Figure 12 . Vertical exaggeration approximately 13 times at sea level.

profiles across the lower trench slopes of arc systems from the Sunda trench [Curray and Moore, 1974; Moore and Karig, 1976b], Java trench [Beck and Lehner, 1974], Aleutian trench [von Huene and Shor, 1969; von Huene, 1972; Grow, 1973], Shikoku trench [Ludwig et al., 1973; Karig et al., 1975; Moore and Karig, 1976a], and the Middle America trench [Ross and Shor, 1965].

The characteristic ridge and basin morphology of deformed sediments above subducting plates has most frequently been explained in terms of a simple imbricate thrust model [e.g., Seely et al., 1974; Karig and Sharman, 1975; Moore and Karig, $1976 b$ ]. Figure 12 diagramatically shows the main features of a model developed from this simple concept which explains the structures observed in the Makran fold belt.

As sediment is scraped off the subducting plate, it becomes deformed into ridges at the frontal fold and is subsequently uplifted along thrust faults. Since folding is initially confined to the uppermost $2-3 \mathrm{~km}$ of sediment, it is possible that the thrust faults flatten out on the decollement zone separating the folded from the undeformed material.

Continued accretion of additional wedges of sediment cause the thrust faults to become progressively steeper towards the coast. This results in tilting of the small ponds of secondarily derived sediment accumulated in the basins between the ridges, a consequence of the model which can be directly tested. As reported by White and Klitgord [1976], the sediment surfaces of material deposited in the interfold basins shows a very small (average of about $0.2^{\circ}$ ), but consistent tilt toward the coast, suggesting that accretionary processes are currently active.
The open ridge and basin structure of the fold belt persists for a distance of 50-100 km north of the frontal folds, where it becomes completely buried by secondarily derived sediment. Original fold ridges can still be seen on the seismic profiles beneath the sediment cover (e.g., 20-40 km on Figure 9). A number of prominent steps in the depth of the sea floor divide the fold belt into two or three separate regions (e.g., see Figures 8 and 10, where the steps are labelled 'fault scar'). The steps are up to $800 \mathrm{~m}$ in height. The peaks of the fold ridges within each region are at approximately uniform depth beneath sea level (see also Figure 5 of White and Klitgord [1976] for further bathymetric profiles illustrating this effect).

It is postulated that these steps in the sea floor are a consequence of major faulting which extends through the entire sediment section (as shown diagrammatically in Figure 12), and thus incorporates the sediment into the accretionary wedge.

The fault scars have average slopes of about $5^{\circ}$. This can be seen more clearly on the bathymetric profile illustrated in Figure 11 at 5 times vertical exaggeration than on the highly exaggerated seismic profile in Figure 10. The angle of rest of the large gravity slumps on the Oman continental margin is also about $5^{\circ}$, and it is probable that the slope of the fault scars is governed by the angle of rest of slumped sediment. Major faulting such as that shown in Figure 12 would create large fault scarps at the sea floor which would subsequently rapidly be eroded by slumping to give fault scars such as we observe.

Evidence for the relatively recent origin of the fault scars is provided by the basins at their foot which are empty of any 


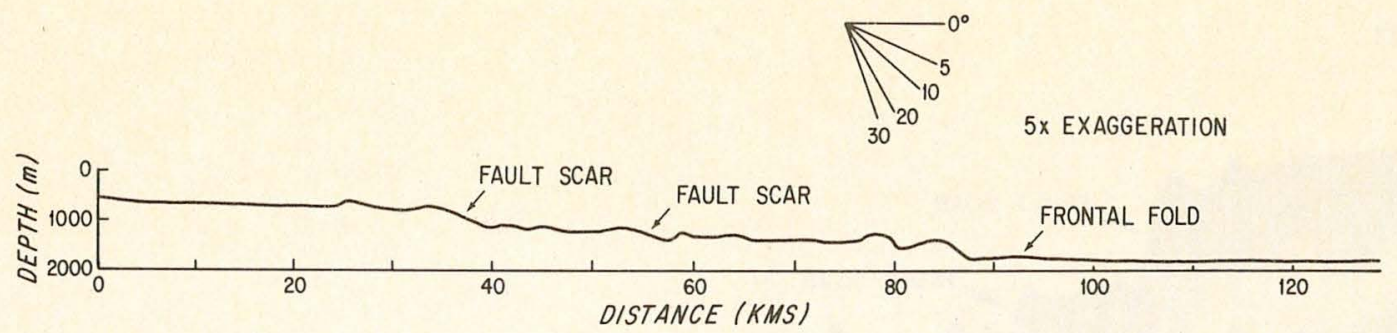

Fig. 11. Bathymetry along seismic profile 22 (illustrated in Figure 10). Vertical exaggeration 5 times. The slope of the fault scars is about $5^{\circ}$, suggesting that they represent slumped sediment (see also Figure 7 ). North is to the left on the figure.

secondary filling of sediment (e.g., at $35 \mathrm{~km}$ on Figure 8; at 36 and $53 \mathrm{~km}$ on Figure 10). The basins must have been created relatively recently or they would be at least partially filled with sediments as are the adjacent interfold basins. A number of high angle faults cutting through the sediments to the north of the present scarp can also be seen on multichannel processed profiles of lines 18 and 19. Model studies of subduction zones by Cowan and Silling [1978] suggest that there may be an upward flow of deeply buried material in the interior of an accretionary prism driven by the normal subduction processes. The elevation of deeply buried, high grade metamorphic rocks reported by these authors would produce large scale secondary faulting such as is observed on our profiles towards the landward margin of the accretionary prism.

The Makran coastal region is seismically active (see Figure 1 of White and Klitgord [1976]), providing further evidence that there is deep structural faulting in this region of the fold belt. It has also been reported that a fault scarp was formed offshore parallel to the coast at the time of the 1945 earthquake of magnitude 8.3 in this area [Sondhi, 1947].

The sedimentology and structure of the broad belt of sediments in the offshore Makran are typical of those found in an accretionary prism. Tectonic structures in the Cretaceous and Cenozoic sediments of the Makran are predominantly eastwest trending, resulting from compression oriented in a northsouth direction [Hunting Survey Corporation, 1960; Falcon, 1974]. Steep folds and reverse faults account for most of the shortening. Farhoudi and Karig [1977] report that lineated slope basins are visible on Landsat images of the Makran.

Subduction zones normally create an area of high pressure metamorphism behind the trench with intrusive andesites fur-

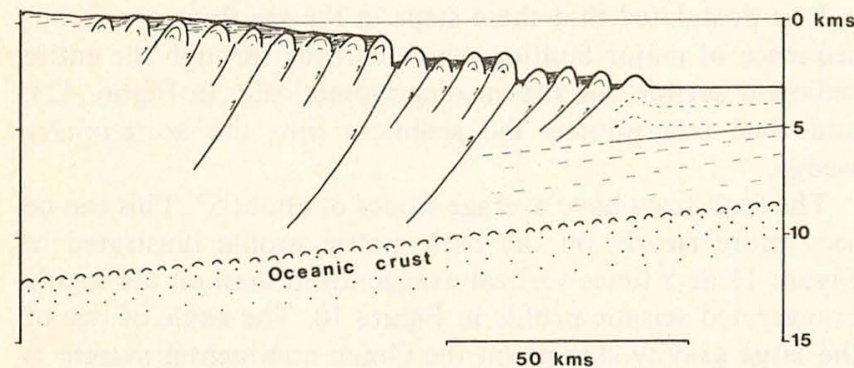

Fig. 12. Diagrammatic model showing the formation of imbricate thrust slices in an accretionary sediment wedge above a subducting oceanic plate. Note that the thrust faults become steeper as they are more deeply entrenched in the accretionary prism. Initially, at the front of the wedge, only the upper $2 \frac{1}{2} \mathrm{~km}$ of sediment is folded and thrust. Active thrusts north of the frontal fold which incorporate material into the accretionary wedge probably penetrate the deeper initially unfolded sediment above the oceanic basement. North is to the left on the figure. ther back. In the Makran, a belt of dynamically metamorphosed sedimentary rocks with axial plane cleavage is found about $200 \mathrm{~km}$ north of the coast. Beyond the metamorphic rocks is an east-west trending belt of mainly basaltic and andesitic submarine volcanics [Hunting Survey Corporation, 1960]. The volcanism was initiated in the Cretaceous, when it became most widespread, and continued throughout the $\mathrm{Ce}$ nozoic. If this is genetically related to the present day plate subduction, a southward migration of the deformational front of several hundred kilometers is suggested. As has been previously noted, successive frontal folds do appear to move southwards. Geological evidence of the progressive displacement through time of the boundary between marine flysch and fresh-water molasse deposits suggests that southward migration of the deformation has been paralleled in the Makran by movement towards the south of the shoreline of $250 \mathrm{~km}$ since the Oligocene [Ahmed, 1969].

The high sedimentation rate in the region is probably responsible for the absence of a topographic trench marking the start of subduction. Rapid sediment loading may cause shallow downbending of the Arabian plate beneath the Makran in a similar way to that observed in Barbados [Westbrook, 1975], thus explaining the widespread shallow seismicity beneath the Makran.

\section{Conclusions}

Convergence between the Arabian and the Eurasian plates gives rise to a variety of different styles of structural deformation in the area between the Gulf of Oman and the Persian Gulf.

In the eastern part of the Gulf of Oman, oceanic crust of the Arabian plate is being subducted northward creating the deformed sediment prism of the Makran. An imbricate thrust model has been proposed to explain the formation of the simple pattern of fold ridges and basins on the continental margin and to suggest how sediment is uplifted along major secondary faults and incorporated into the accretionary prism which extends northward into Iran and Pakistan.

Towards the western end of the Gulf of Oman continued convergence has brought the opposing Oman continental margin into collision with the Makran margin. At present only the outer edges of the sediment prisms are in contact. Open folds can be seen forming on the edge of the steep but previously unfolded continental margin of Oman.

The Oman line, which runs along the eastern edge of the Strait of Hormuz, marks the boundary between the oceanic crust of the Gulf of Oman and the edge of the Arabian continental shield to the west. West of the Oman line the EurasianArabian convergence is at a continent-continent type boundary. A single profile north of the Musandam Peninsula (profile $15)$, exhibits a large buried basement ridge which is interpreted 
from seismic reflection, gravity and magnetic measurements as being a northward continuation of the peninsula. Although the seismic profile only reveals the upper part of the basement, it is likely that part of the Arabian plate is underthrusting the Eurasian plate in this region.

Acknowledgments. We wish to thank the officers and crew of $\mathrm{R} / \mathrm{V}$ Atlantis II for their assistance and good seamanship in helping us to obtain the seismic profiles in these congested waters. Manik Talwani kindly supplied a listing of the R/V Meteor 1965 gravity data from the area, and Robert B. Whitmarsh graciously supplied details of crossover errors with gravity values from Shackleton cruise $4 / 75$. We thank Carl Bowin for supplying details of land gravity data from Iran. A special thanks is due the multichannel seismics group at Woods Hole who obtained (Keith von der Heydt, Thomas F. O'Brien, and Daniel R. Shaughnessy III) and processed the data (Kenneth E. Prada, David H. Gever, and Daniel R. Shaughnessy III). James Jackson, Carl Bowin, Mike Purdy, John Dewey, and Dan Karig offered suggestions which greatly improved the manuscript. D. S. Cowan kindly made a pre-print of his modelling paper available to us. The expedition was funded by a grant from the National Science Foundation Oceanography Section (grant 76-10417). Robert S. White was supported while doing this work by a grant from the Maurice Hill Research Fund from the Royal Society and by a Harkness scholarship from Cambridge University. David A. Ross was supported by the above mentioned NSF grant and by a contract with the Office of Naval Research Woods Hole Oceanographic Institution contribution 4196.

\section{REFERENCES}

Ahmed, S. S., Tertiary geology of part of south Makran, Baluchistan, West Pakistan, Amer. Ass. Petrol. Geol. Bull., 53, 1480-1499, 1969.

Ala, M. A., Salt diapirism in Southern Iran, Amer. Ass. Petrol. Geol. Bull., 58, 1758-1770, 1974.

Allemann, F., and T. Peters, The ophiolite-radiolarite belt of the north-Oman mountains, Ecol. Geol. Helv., 65, 657-697, 1972.

Beck, R. H., and P. Lehner, Oceans, New frontier in exploration, Amer. Ass. Petrol. Geol. Bull., 58, 376-395, 1974.

Berberian, M., Contribution to the seismotectonics of Iran, part II, Rep. 39, 516 pp., Geol. Surv. of Iran, Tehran, 1976.

Carson, B., J. Yuan, P. B. Myers, Jr., and W. D. Barnard, Initial deep sea sediment deformation at the base of the Washington continental slope; A response to subduction, Geology, 12, 561-564, 1974.

Cornelius, P. F. S., N. L. Falcon, D. South and C. Vita-Finzi, The Musandam expedition 1971-72 scientific results, 1, Geogr. J., 139, 400-425, 1973.

Cowan, D. S., and R. M. Silling, A dynamic, scaled model of accretion at trenches and its implications for the tectonic evolution of subduction complexes, J. Geophys. Res., 83, 5389-5396, 1978.

Curray, J. R., and D. G. Moore, Sedimentary and tectonic processes in the Bengal deep-sea fan and geosyncline, in Geology of Continental Margins, edited by C. A. Burk and C. L. Drake, pp. 617-627, Springer, New York, 1974.

Falcon, N. L., Vertical and horizontal earth movements, Geogr. J., 139, 404-409, 1973.

Falcon, N. L., An outline of the geology of the Iranian Makran, Geogr. J., 140, 284-291, 1974.

Falcon, N. L., From Musandam to the Iranian Makran, Geogr. J., $141,55-58,1975$.

Farhoudi, G., and D. E. Karig, Makran of Iran and Pakistan as an active arc system, Geology, 5, 664-668, 1977.

Gardner, G. H. F., L. W. Gardner, and A. R. Gregory, Formation velocity and density-The diagnostic basics for stratigraphic traps, Geophysics, 39, 770-780, 1974.

Glennie, K. W., M. G. A. Boeuf, M. W. Hughes Clark, M. MoodyStuart, W. H. F. Pilaar, and B. M. Reinhardt, Late Cretaceous nappes in Oman mountains and their geologic evolution, Amer. Ass. Petrol. Geol. Bull., 57, 5-27, 1973.

Grow, J. A., Crustal and upper mantle structure of the central Aleutian Arc, Geol. Soc. Amer. Bull., 84, 2169-2192, 1973.

Heezen, B. C., and C. L. Drake, Grand Banks slump, Amer. Ass. Petrol. Geol. Bull., 48, 221-225, 1964.

Hudson, R. G. S., The Permian and Trias of the Oman Peninsula, Arabia, Geol. Mag., 97, 299-308, 1960.

Hudson, R. G. S., A. McGugan, and D. M. Morton, The structure of the Jebel Hagab area, Trucial Oman, Quart. J. Geol. Soc. London, $60,121-157,1954$
Hunting Survey Corporation, Reconnaissance Geology of Part of West Pakistan, Maracle Press, Toronto, Ont., 1960.

Jacob, K. H., and R. C. Quittmeyer, The Makran region of Pakistan and Iran: Trench-ore system with active plate subduction, Pakistan Geol. Mem., 11, 1978 .

Karig, D. E. and G. F. Sharman, Subduction and accretion in trenches, Geol. Soc. Amer. Bull., 86, 377-389, 1975.

Karig, D. E., et al., Initial reports of the deep sea drilling project, vol. 31 , pp. 317-350, U.S. Govt. Printing Office, Washington, D. C.. 1975.

Kulm, L. D., and G. A. Fowler, Oregon continental margin structure and stratigraphy, in The Geology of Continental Margins, edited by C. A. Burk and C. L. Drake, pp. 261-283, Springer, New York, 1974.

Kulm, L. D., and R. A. Prince, Site survey of northern Oregon continental margin and Astonia fan, Initial reports of the deep sea drilling project, vol. 18, pp. 979-987, U.S. Govt. Printing Office, Washington, D. C., 1973.

Lees, G. M., Geology and tectonics of Oman and parts of S.E. Arabia, Quart. J. Geol. Soc. London, 84, 585-670, 1928.

Ludwig, W. J., N. Den, and S. Murauchi, Seismic reflection measurement of southwest Japan margin, J. Geophys. Res., 78, 2508-2516, 1973.

Mina, P., M. T. Razaghnia, and Y. Paran, G eological and geophysical studies and exploratory drilling of the Iranian continental shelf, Persian Gulf, Bull. Iranian Petrol. Inst., 28, 61-96, 1967.

Moore, J. C., and D. E. Karig, Sedimentology, structural geology, and tectonics of the Shkoku subduction zone, southwestern Japan, Geol. Soc. Amer. Bull., 87, 1259-1268, 1976a.

Moore, G. F., and D. E. Karig, Development of sedimentary basin on the lower trench slope, Geology, 4, 693-697, $1976 b$.

Morris, P., Basement structure as suggested by aeromagnetic surveys in southwest Iran, Iran. Petrol. Inst., Tehran, in press, 1979.

Nowroozi, A. A., Seismotectonic provinces of Iran, Bull. Seismol. Soc. Amer., 66, 1249-1276, 1976.

Peter, G., and G. K. Westbrook, Tectonics of Southwestern North Atlantic and Barbados Ridge complex, Amer. Ass. Petrol. Geol. Bull., 60, 1078-1106, 1976.

Roberts, D. G., Slumping on the eastern margin of the Rockall Bank in the North Atlantic Ocean, Mar. Geol., 13, 225-237, 1972.

Ross, D. A., and G. G. Shor, Jr., Reflection profiles across the middle American Trench, J. Geophys. Res., 70, 5551-5572, 1965.

Seely, D. R., P. R. Vail, and G. G. Walton, Trench slope model, in The Geology of Continental Margins, edited by C. A. Burk and C. L. Drake, pp. 249-260, Springer, New York, 1974.

Shearman, D. J., The geological evolution of southern Iran, Geogr. J., 142, 393-410, 1976.

Silver, E. A., Late Cenozoic underthrusting of the continental margin off northernmost California, Science, 166, 1265-1266, 1969.

Silver, E. A., Transitional tectonics and late Cenozoic structure of the continental margin off northernmost California, Geol. Soc. Amer. Bull., 82, 1-22, 1971

Sondhi, V. P., The Makran earthquake, 28th November, 1945, The birth of new islands, Indian Miner., 1(3), 146-154, 1947.

South, D., Pre-quaternary geology, Geogr. J., 139, 410-414, 1973.

von Huene, R., Structure of the continental margin and tectonism of the eastern Aleutian trench, Geol. Soc. Amer. Bull., 83, 3613-3626, 1972.

von Huene, R., and G. G. Shor, Jr., The structure and tectonic history of the eastern Aleutian trench, Geol. Soc. Amer. Bull., 80, 1889$1902,1969$.

Westbrook, G. K., The structure of the crust and upper mantle in the region of Barbados and the lesser Antilles, Geophys. J. Roy. Astron. Soc., 43, 201-242, 1975.

White, R. S., Recent fold development in the Gulf of Oman, Earth Planet. Sci. Lett., 36, 85-91, $1977 a$.

White, R. S., Deformation of the Makran continental margin, Pakistan Geol. Mem., 11, 1979.

White, R. S., and K. D. Klitgord, Sediment deformation and plate tectonics in the Gulf of Oman, Earth Planet. Sci. Lett., 32, 199-209, 1976.

(Received July 26, 1978; revised October 24, 1978; accepted January 11, 1979.) 


\section{MANDATORY DISTRIBUTION LIST \\ FOR UNCLASSIFIED TECHNICAL REPORTS, REPRINTS, AND FINAL REPORTS \\ PUBLISHED BY OCEANOGRAPHIC CONTRACTORS \\ OF THE OCEAN SCIENCE AND TECHNOLOGY DIVISION \\ OF THE OFFICE OF NAVAL RESEARCH}

(REVISED NOVEMBER 1978)

1 Deputy Under Secretary of Defense

(Research and Advanced Technology)

Military Assistant for Environmental Science Room 3D129

Washington, D.C. 20301

Office of Naval Research

800 North Quincy Street

Arlington, VA 22217

3 ATTN: Code 483

1 ATTN: Code 460

2 ATTN: 102B

1 CDR J. C. Harlett, (USN)

ONR Representative Woods Hole Oceanographic Inst.

Woods Hole, MA 02543

Commanding Officer

Naval Research Laboratory

Washington, D.C. 20375

6 ATTN: Library, Code 2627
12 Defense Documentation Center Cameron Station

Alexandria, VA 22314

ATTN: DCA

Commander

Naval Oceanographic Office NSTL Station

Bay St. Louis, MS 39522

1 ATTN: Code 8100

1 ATTN: Code 6000

1 ATTN: Code 3300

1 NODC/NOAA

Code D781

Wiscons in Avenue, N.W. Washington, D.C. 20235 


\begin{tabular}{|c|c|}
\hline REPORT DOCUMENTATION PAGE & $\begin{array}{l}\text { READ INSTRUCTIONS } \\
\text { BEFORE COMPLETING FORM }\end{array}$ \\
\hline \begin{tabular}{l|l} 
1. REPORT NUMBER & 2. GOVT ACCESSION NO. \\
WHOI $-79-98$ &
\end{tabular} & 3. RECIPIENT'S CATALOG NUMBER \\
\hline $\begin{array}{l}\text { 4. TITLE (and Subtitte) } \\
\text { TECTONICS OF THE WESTERN GULF OF OMAN }\end{array}$ & $\begin{array}{l}\text { 5. TYPE OF REPORT \& PERIOD COVERED } \\
\text { Technical }\end{array}$ \\
\hline & $\begin{array}{l}\text { 6. PERFORMING ORG. REPORT NUMBER } \\
\text { WHOI CON. NO. } 4196\end{array}$ \\
\hline $\begin{array}{l}\text { 7. AUTHOR(s) } \\
\text { Robert S. White and David A. Ross }\end{array}$ & $\begin{array}{l}\text { 8. CONTRACT OR GRANT NUMBER(ध) } \\
\text { N00014-74-C-0262; } \\
76-10417\end{array}$ \\
\hline $\begin{array}{l}\text { 9. PERFORMING ORGANIZATION NAME AND ADDRESS } \\
\text { Woods Hole Oceanographic Institution } \\
\text { Woods Hole, MA } 02543\end{array}$ & $\begin{array}{l}\text { 10. PROGRAM ELEMENT, PROJECT, TASK } \\
\text { AREA \& WORK UNIT NUMBERS } \\
\text { NR } 083-004\end{array}$ \\
\hline $\begin{array}{l}\text { 11. CONTROLLING OFFICE NAME AND ADDRESS } \\
\text { NORBA }\end{array}$ & $\begin{array}{l}\text { 12. REPORT DATE } \\
\text { December } 1979\end{array}$ \\
\hline $\begin{array}{l}\text { National Space Technology Laboratory } \\
\text { Bay St. Louis, MS } 39529\end{array}$ & 13. NUMBER OF PAGES \\
\hline 14. MONITORING AGENCY NAME \& ADDRESS(If different from Controlline Office) & $\begin{array}{l}\text { 15. SECURITY CLASS. (of thio roport) } \\
\text { UnClaSS ified } \\
\text { 15. DECLASSIFICATION/DOWNGRADING } \\
\text { SCHEDULE }\end{array}$ \\
\hline
\end{tabular}

16. DISTRIBUTION STATEMENT (of thlo Roport)

Approved for public release; distribution untimited.

17. DISTRIBUTION STATEMENT (of the abotract ontered In Block 20, if different from Report)

18. SUPPLEMENTARY NOTES

Reprinted from "Journal of Geophysical Research, Vo1. 84, No. B7, July 10, 1979, pp. 3479-3489".

19. KEY WORDS (Continue on reverse sido if nocessary and ldentlly by block number)

1. Gulf of Oman

2. Tectonics

3. Subduction

20. ABSTRACT (Continue on reverso eide if necesengy and ldentily by block number)

Refer to page 3479 for abstract. Extensive in length. 


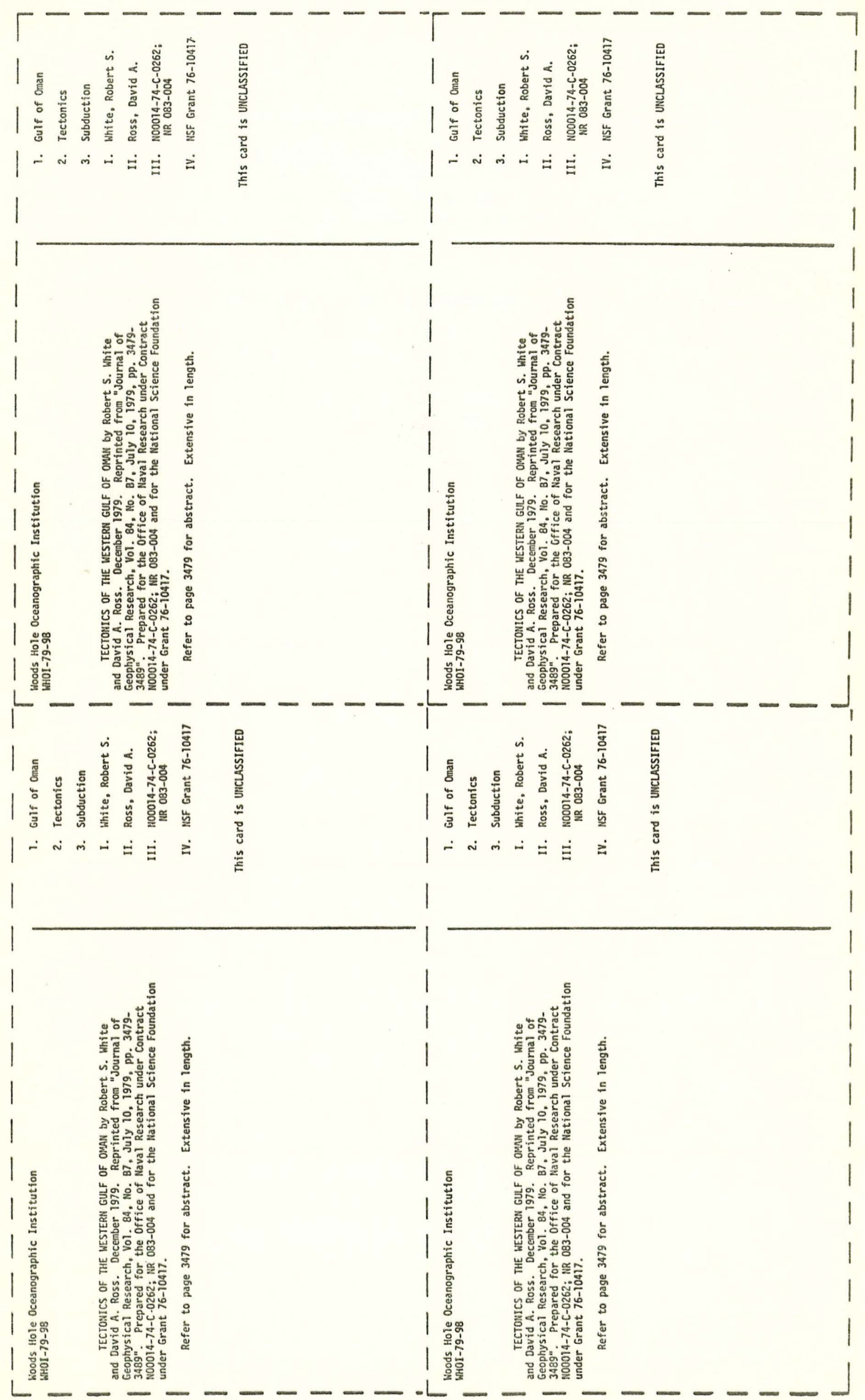

